\title{
PKM SISTEM INFORMASI DESA BRINGKANG SEBAGAI PORTAL DESA
}

\author{
Suryo Atmojo ${ }^{1}$, Randy Dwi Romadhoni ${ }^{2}$ \\ ${ }^{1}$ Universitas Wijaya Putra \\ ${ }^{2}$ Universitas Wijaya Putra \\ suryoatmojo@uwp.ac.id, \\ randy.romadhoni@gmail.com
}

\begin{abstract}
Abstrak
Pembangunan pedesaan mengalami perubahan signifikan seiring pesatnya perkembangan Teknologi Informasi dan Komunikasi. Infrastruktur (TIK). TIK berdampak besar terhadap pembangunan pedesaan. Desa-desa yang selama ini termarjinalkan dalam peta TIK kini perlahan-lahan mulai dikenal secara global.

Desa Bringkang merupakan salah satu desa yang berada pada Kecamatan Menganti di Kabupaten Gresik Jawa Timur. Desa ini memiliki lokasi yang cukup dekat dengan kota-kota besar, seperti Surabaya, Mojokerto dan Sidoarjo. Hal ini memungkinkan cukup banyak penduduk yang merupakan pendatang dari kota-kota besar dan akses penyebaran teknologi ke Desa Bringkang semakin tinggi sehingga penduduk melek teknologi semakin banyak. Desa Bringkang memiliki 8 perangkat desa, tetapi perangkat desa yang merupakan pengadopsi teknologi hanya 1 orang dari 8 orang, meskipun sudah ada pembinaan dan pelatihan penggunaan teknologi untuk perangkat desa hanya beberapa yang mengimplementasikannya.

Berdasarkan permasalahan tersebut, sangat diperlukan adanya portal desa dengan penyuluhannya, guna mengoptimalkan informasi yang terserap oleh warga dan aspirasi. Hasil dari kegiatan ini, 93\% masyarakat menilai portal mudah digunakan oleh masyarakat desa, dengan $87 \%$ masyarakat menilai pentingnya sistem informasi desa untuk penyebaran informasi di desa
\end{abstract}

Kata Kunci : Sistem, Desa, Portal, Informasi 


\section{PENDAHULUAN}

Untuk menjamin sebuah pedesaan dapat mengalami perubahan yang signifikan seiring pesatnya perkembangan Teknologi Informasi dan Komunikasi (TIK). Teknologi Informasi dan Komunikasi (TIK) memberikan pengaruh besar terhadap pembangunan pedesaan. Desa-desa yang selama ini termarjinalkan dalam peta TIK kini perlahan-lahan mulai dikenal secara global. Ketertinggalan desa dari perkembangan TIK selama ini disebabkan kebijakan dan program-program pemerintah pusat yang sering menempatkan desa sebagai objek bukan sebagai subjek, programprogram pemanfaatan TIK hanya sampai pada tingkat

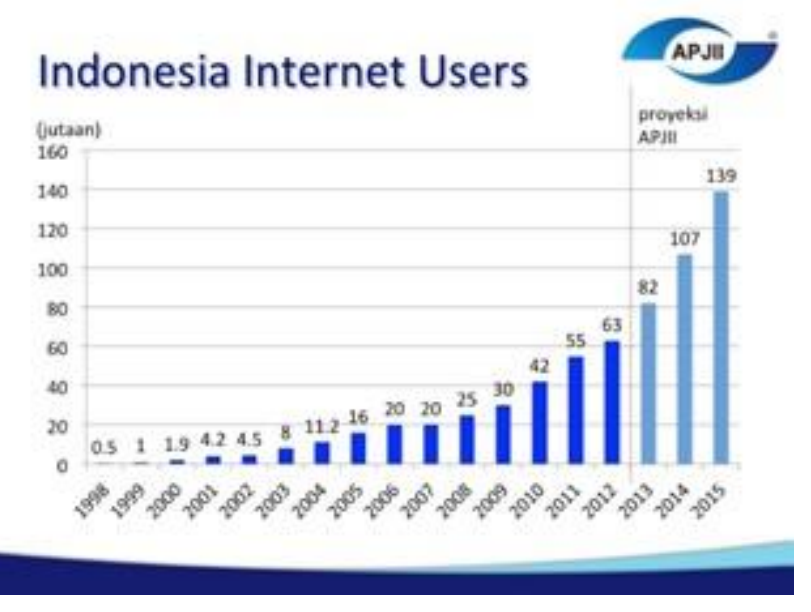

Gambar 1. Statistik Pengguna Internet Indonesia (Sumber : APJII)

kabupaten atau kecamatan.Oleh karena itu, dengan munculnya gerakan dari desa yang dapat menyelenggarakan pemerintahan secara baik dan mandiri, yang didukung dengan pemanfaatan TIK, menjadi pelajaran bahwa inisiatif tersebut dapat dilakukan dari bawah (Praditya, 2014: 130). Berdasarkan APJII (Asosiasi Penyelenggara Jasa Internet Indonesia) pengguna internet di Indonesia setiap tahunnya meningkat secara signifikan (gambar 1). Penggunaan internet di Indonesia akan sangat mendukung perkembangan penyebaran informasi dan perlu diadakannya peningkatan media dalam penyebaran informasi dari berbagai elemen secara bertahap guna memaksimalkan pemanfaatan internet untuk kemajuan bangsa Indonesia.

Desa Bringkang merupakan salah satu desa yang berada pada Kecamatan Menganti di Kabupaten Gresik Jawa Timur. Desa ini memiliki kemungkinan bahwa banyak penduduk yang merupakan pendatang dari kota-kota besar dan akses penyebaran teknologi ke Desa Bringkang semakin tinggi sehingga dapat membuat penduduk melek teknologi juga semakin banyak. Desa Bringkang merupakan pengadopsi teknologi yang sedang dibutuhkan oleh para perangkat desa, meskipun telah adanya pelatihan tentang teknologi namun tidak dapat terimplemantasikan secara maksimal.

Melalui Program Kreativitas Mahasiswa Pengabdian Masyarakat ini diperlukan pelatihan dan pendampingan penggunaan website SIFORSA dan Mobile SIFORSA yaitu suatu program yang dapat mengoptimalkan informasi yang terserap oleh warga dan aspirasi warga dapat tertampung dengan optimal dan maksimal. Sehingga dengan adanya Program ini warga memiliki keterlibatan seluruh warga dalam pembangunan desa bisa tercapai dan berdampak baik kedepannya.

\section{METODE}

Tahapan pertama dari pengabdian ini yaitu Penyuluhan. Teknik penyuluhan berguna untuk menyukseskan teknik pelatihan. Teknik penyuluhan dilakukan tim PKM terdiri dari Rapat Anggota, Survei lokasi, perijinan, kerjasama dan Rapat koordinasi. Pada proses penyuluhan terdiri dari beberapa kegiatan diataranya adalah rapat Anggota. Kegiatan ini bertujuan untuk menyearahkan persepsi anggota dengan ketua. Rapat Anggota membahas hal umum tentang keberlanjutan program, langkah strategis yang akan diambil dan membagi tugas setiap anggota. Kegiatan berikutnya yaitu rapat koordinasi, bertujuan untuk menyearahkan persepsi tim PKM dengan pembimbing. Rapat koordinasi diperlukan untuk mendapat masukan pembimbing serta membahas langkah strategis yang akan diambil dalam hal pelaksanaan dan keberlanjutan. Kegiatan berikutnya yaitu survei lokasi, bertujuan untuk melihat latar belakang pendidikan, masyarakat dan wilayah lebih detail. Latar belakang pendidikan berpengaruh terhadap sasaran program. Kondisi masyarakat akan

Teknologi Informasi dan Komunikasi 
mempengaruhi cara penyampaian dalam pelatihan. Kondisi wilayah berguna untuk menentukan lokasi pelatihandan penempatan teknologi. Aktifitas berikutnya adalah melakukan perijinan dimana bertujuan untuk menjalin hubungan yang terlindung secara hukum antara tim PKM dengan objek sasaran program. Perijinan dilakukan didesa Bringkang, Kec.Menganti Kab.Gresik. perijinan terdiri dari perijinan pelaksanaan dan komponen pendukung pelaksanaan. Komponen pendukung pelaksanaan terdiri dari pinjam tempat, pinjam perlengkapan, pinjam peralatan. Kegiatan selanjutnya yaitu melakukan kerjasama, bertujuan untuk memperkuat teknik pelatihan dan mencari dukungan dengan instansi lain.

Tahapan kedua yaitu pelatihan, bertujuan untuk mencetak generasi yang mengerti tentang teknologi Sistem informasi desa. Teknik pelatihan yang digunakan tim pkm terdiri dari ceramah, praktik, presentasi mandiri, diskusi, pemasangan teknologi.

Tahapan ketiga yaitu pendampingan IPTEK yang dilakukan oleh tim PKM adalah pembentukan organisasi, perekrutan anggota, pendidikan jarak jauh dan pengembangan mandiri

\section{HASIL DAN PEMBAHASAN}

\section{Gambaran Umum}

Desa Bringkang, kec. Menganti kab. Gresik Merupakan wilayah salah satu desa yang terletak 20 $\mathrm{km}$ dari Kabupaten Gresik dengan batas wilayah : sebelah barat berbatasan dengan Desa Mojotengah, sebelah timur Desa Pranti, sebelah utara Kecamatan Kedamean, sebelah selatan Desa Domas. Desa Bringkang terletak 13,4 KM dari Kampus I Universitas Wijaya Putra di Jl. Raya Benowo No. 1-3 Surabaya, dengan koordinat terletak di titik koordinat -7.295119 Lintang Selatan dan 112.557094 Bujur Timur. Memiliki luas wilayah 261,51 Ha. Luas daerah ini sekitar 3.430 m2.

\section{Tabel 1. Jumlah Penduduk Bringkang}

Berdasarkan data yang telah kami kumpulkan dari aparat desa dan warga desa, Bringkang adalah salah satu desa yang berada pada Kecamatan Menganti,
Kabupaten Gresik. Desa Bringkang memiliki kurang lebih 5068 jiwa dan luas wilayah kurang lebih 3,43 km persegi. Desa Bringkang memiliki 8 perangkat desa, tetapi hanya 1 yang akrab dengan teknologi. Penduduk di Desa Bringkang terbagi menjadi 2 yaitu penduduk yang lahir di Kabupaten Gresik dan penduduk pendatang dengan masingmasing jumlah 2911 jiwa dan 2157 jiwa serta dengan persentase masing-masing $52 \%$ dan $48 \%$.

Perangkat desa juga bukan pengguna teknologi secara aktif sehingga menyebabkan mekanisme penyampaian informasi terlalu panjang dan tidak merata dikarenakan menggunakan surat. Maka dengan mekanisme penyampaian informasi di Desa Bringkang yaitu dengan memberikan undangan berupa surat yang ditujukan ke Ketua RW di teruskan ke Ketua RT lalu di lanjutkan ke Dasa Wisma dan terakhir informasi diterima oleh warga. Berdasarkan permasalahan tersebut hal ini kurang efektif dikarenakan pemborosan waktu, biaya dan itupun belum tentu tersebar merata. Di Desa Bringkang belum memiliki tempat untuk menampung aspirasi warga desa secara online, sehingga mekanisme penyampaian kritik dan saran warga dilakukan dengan cara mendatangi rumah kepala desa atau datang langsung ke kelurahan. Serta belum adanya forum yg bersifat terbuka dan dinamis.

Ruang lingkup pengaturan Hak Masyarakat Desa diatur yang dalam undang-undang Desa pasal 68 berkaitan dengan hak untuk meminta dan mendapatkan informasi, memperoleh pelayanan, menyampaikan aspirasi, memilih dan dipilih, dan mendapatkan pengayoman dan perlindungan dari gangguan ketenteraman dan ketertiban. Dengan adanya permasalahan tersebut dan peraturanperaturan yang mengatur desa, sangat diperlukan adanya SIFORSA (Sistem Informasi Desa) Bringkang dan dengan pelatihan serta pendampingan kepada perangkat desa, guna memaksimalkan informasi yang terserap oleh warga serta aspirasi warga dapat tertampung dengan optimal dan maksimal. Sehingga keterlibatan seluruh warga dalam pembangunan desa bisa tercapai dan berdampak baik kedepannya.

\section{Pengertian Sistem Informasi pengolahan data}

Teknologi Informasi dan Komunikasi 
Berdasarkan (Fadilah \& Erza, 2017) metode yang dapat digunakan padapengabdiaan menggunakan sistem informasi ini adalah dengan mengembangkan administrasi pelayanan dengan sistem terkomputerisasi. Penyederhanaan dalam penyampaian informasi yang dibutuhkan bagi pengambilan keputusan teerhadap aspek perencanaan, pemrakaarsaan, pengorganisasian dan pengawasan berdasarkan data kependudukan yang ada.

\section{Diagram DAD}

Menurut (Syarif \& Cisde, 2015) diagram alir data adalah bagan yang menjelaskan arus atau aliran data pada sebuah system. Diagaram alir data dapat mempermudah proses perancangan system. Diagram alir data perancangan system informasi desa terdapat pada gambar dibawah ini.

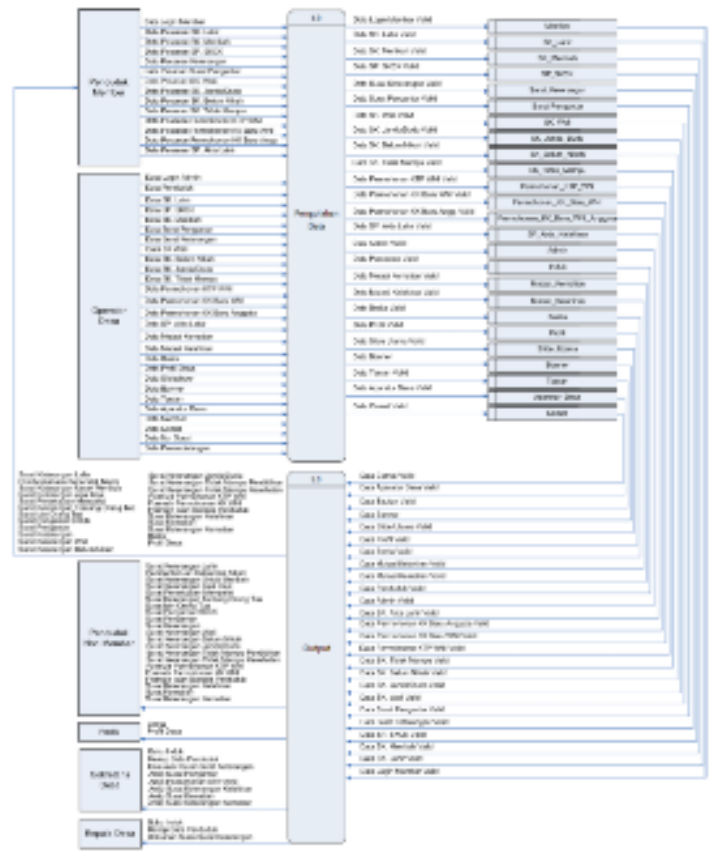

Gambar 1. Diagram arus data

\section{Perancangan Basis data}

Pada pembuatan system informasi desa bringkang ini membutuhkan gambaran perancangan database. Berikut rancangan database sistem informasi desa (Syarif \& Cisde, 2015).

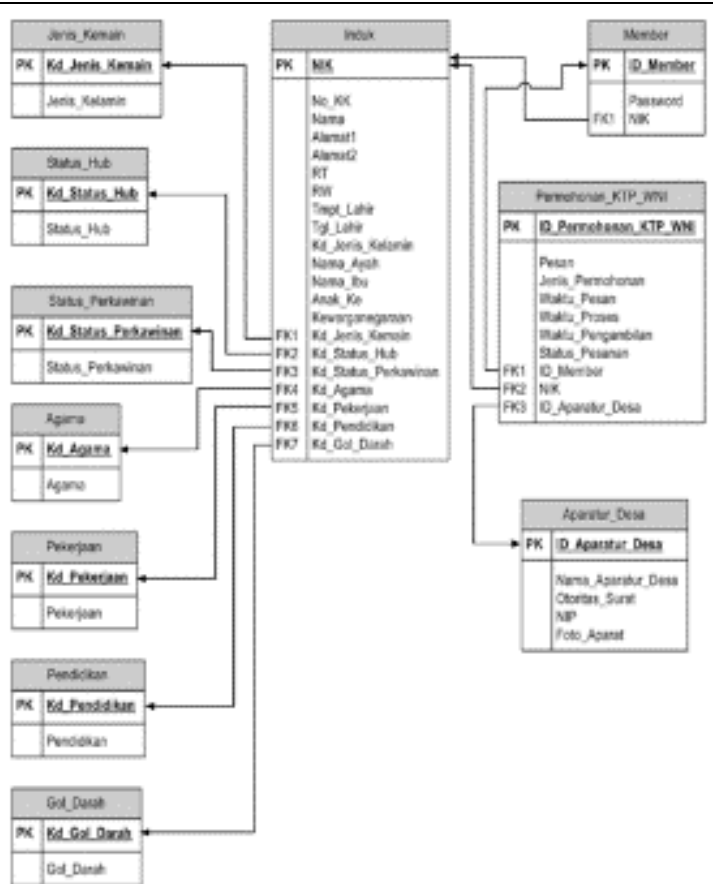

Gambar 2. Relasi Tabel

\section{Implementasi sistem}

Sistem informasi desa Bringkang ini terbagi menjadi dua bagian yaitu front end yang dapat diakses oleh penduduk member maupun public dan back end yang hanya dapat di akses oleh perangkat desa.

Untuk dapat mengakses berita dan profil desa pada bagian front end, penduduk member maupun publik tidak perlu melakukan proses login.

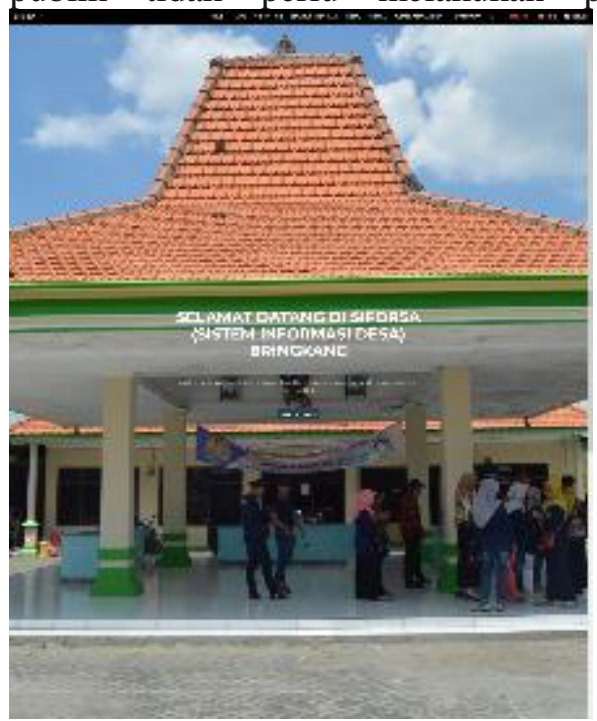

Gambar 3. Tampilan homepage 
Cukup dengan masuk ke halaman homepage seperti pada gambar 3. Namun untuk dapat mengakses layanan administrator, hanya penduduk member dengan aturan admin yang dapat melakukannya, dan setelah melewati proses login dengan memasukkan username dan password yang benar sehingga dapat mengakses halaman administrator seperti gambar 4 .

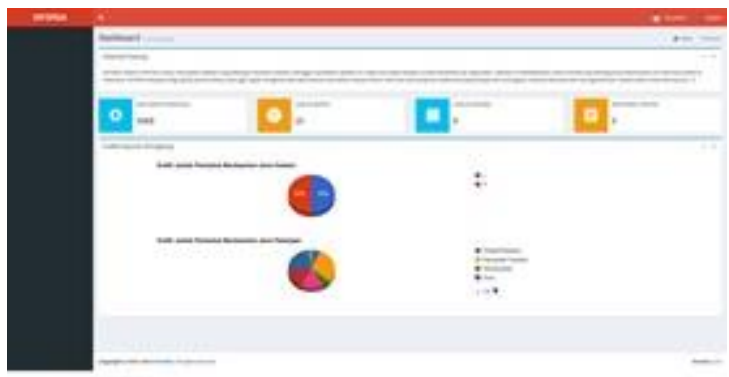

Gambar 4. Halaman dashboard

. Untuk mengakses bagian back end, operator desa harus melewati proses login terlebih dahulu dengan memasukkan nama admin dan password yang tepat. Jika berhasil, akan ditampilkan dashboard (Gambar 4). Setelah itu perangkat desa dapat mengelola administrasi kependudukan yang meliputi pengelolaan pesanan surat, membuat surat secara langsung, maupun pengelolaan data penduduk, dan lain-lain. Selain itu, operator desa juga dapat mengelola website desa yang berisi berita-berita dan profil desa. Adapun menu menu administrator dapat dilihat pada gambar di bawah ini

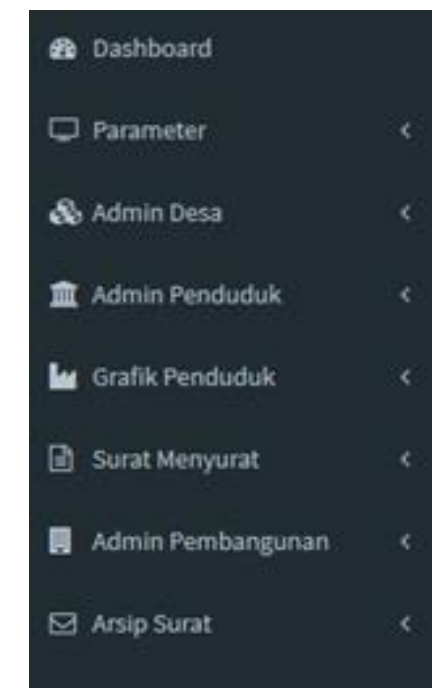

Gambar 5. Menu back end sistem inforamsi desa
Selain website, sistem informasi desa ini juga dapat di akses melalui aplikasi mobile, sehingga memudahkan masyarakat desa bringkat untuk mengakses seputar berita terkait desa. Beberapa tim yang terkait dengan pembuatan aplikasi mobile untuk desa brikang seperti gambar dibawah ini.

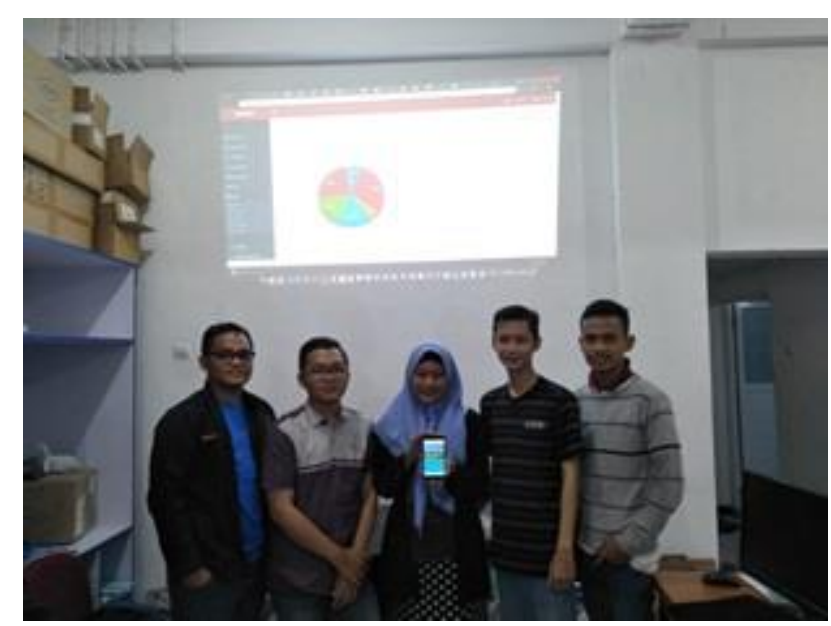

Gambaar 6. Tim pembuatan apliaksi mobile sistem informasi desa bringkang

\section{Manfaat Program Siforsa}

Manfaat program SIFORSA antara lain yaitu 1) Mekanisme penyebaran informasi menjadi lebih cepat dan praktis dengan adanya website dan aplikasi SIFORSA. 2) Mempermudah menampung segala kritik dan saran warga desa guna pembangunan desa. 3) Pemanfaatan forum desa guna wadah diskusi secara terbuka dan dinamis, sehingga semua warga bisa berpartisipasi dalam pembangunan desa.

4) Ketergantungan masyarakat akan penggunaan sistem manual menjadi berkurang.

5) Diharapkan perangkat desa dapat melakukan troubleshouting secara mandiri.

\section{Hasil Pengabdian}

Program SIFORSA (Sistem Informasi Desa Bringkang) yang dilaksanakan di Desa Bringkang Kecamatan Menganti, Kabupaten Gresik dapat dinilai sudah berjalan dengan baik pasalnya semua kegiatan yang dilakukan sesuai dengan timeline Teknologi Informasi dan Komunikasi 
yang sudah terjadwal. Langkah pertama dalam program ini adalah survei lokasi awal yang tujuannya adalah mengetahui permasalahan dan potensi yang ada di desa tersebut. Pada proses survey, pelaksanaannya dengan cara menggali informasi dari beberapa perangkat desa.

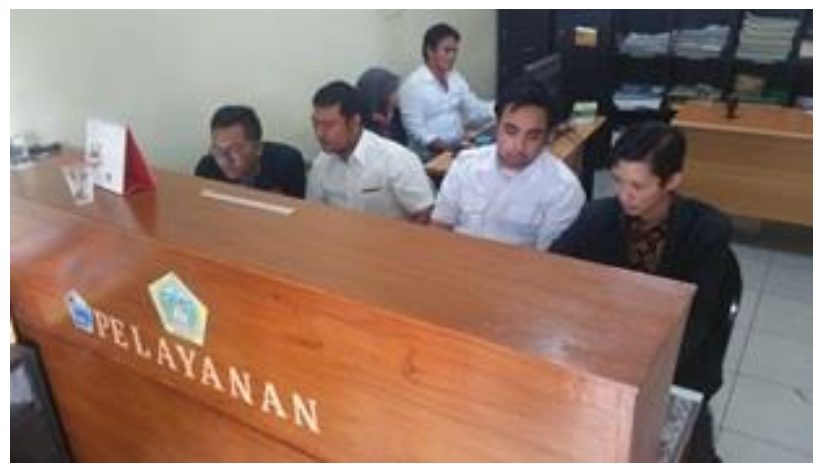

Gambar 7. Penggalian data administrasi desa

Gambar 7 merupakan proses penggalian data administrasi desa untuk menggali informasi data apa saja yang selama ini dibutuhkan oleh masyarakat desa bringkang. Penggalian data tidak hanya dilakukan dengan cara melihat sistem sistem apa saja yang sudah berjalan melainkan juga dengan cara berdiskusi dengan perangkat desa bringkang

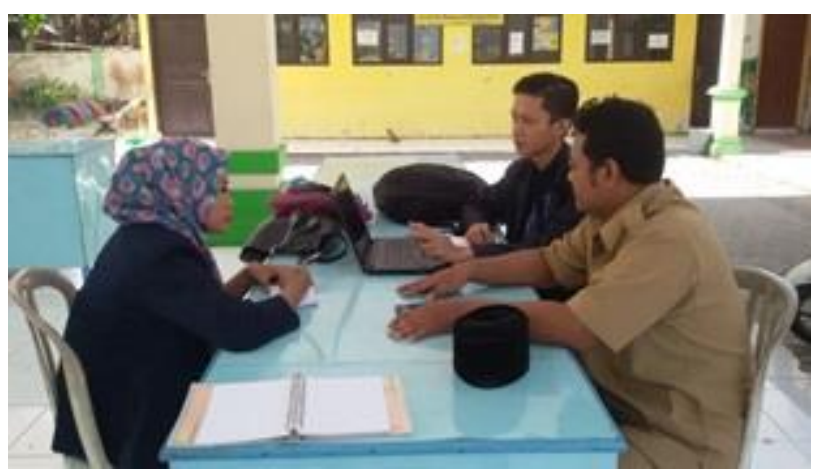

Gambar 8. Diskusi dengan perangkat desa bringkang

Gambar 8 merupakan proses diskusi dengan perangkat desa untuk mengetahui permsasalahn permasalahn yang selama ini ada di desa bringkang. Setelah permasalahan dan potensi tersebut benarbenar dapat dimanfaatkan, langkah selanjutnya adalah melakukan perijinan serta konsultasi pada berbagai pihak terutama kepada Kepala Desa Bringkang dan dengan izin para perangkatperangkat desa. Respon dari pihak-pihak tersebut sangat baik dan mendukung adanya program, yang diharapkan pula dapat berkembang dan diikuti oleh semua perangkat desa dan warga yang mendukung adanya kemudahan dalam menjalankan teknologi.

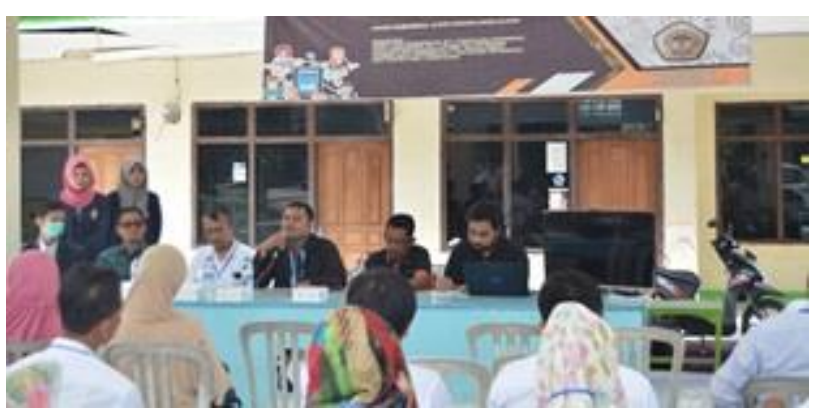

Gambar 9. Sosialisasisistem informasi desa

Gambar 9 merupakan kegaiatan sosialisasi sistem informasi desa bringkan. Sosialisasi awal dilakukan pada tanggal 23 juni 2018 yang diikuti oleh warga Desa Bringkang, respon warga dalam pengenalan awal ini sangat baik mereka mendukung sepenuhnya program ini, hal tersebut diketahui dari kuisioner yang diberikan kepada warga. Kegiatan selanjutannya adalah dengan terjun langsung ke perangkat desa sebagai sarana pelatihan untuk perangkat desa memahami program yang dibuat sebelum dapat melayani warga Desa Bringkang, pengenalan program lebih jauh dan sosialisasi tentang adanya program disetiap rumah baik melalui kegiatan PKK ataupun dalam kegiatan pengajian. Adapun hasil yang telah dicapai adalah program kami dapat memudahkan perangkat desa untuk mempublikasikan segala informasi terkait dengan desa secara umum, mengoptimalkan penyerapan aspirasi warga untuk meningkatkan peran serta warga desa dalam pembangunan desa, menggunakan media website dan mobile dengan tampilan yang mudah di mengerti oleh segala umur. Proses pembuatan Website adalah hasil diskusi bersama dengan perangkat - perangkat desa Bringkang supaya mereka dapat lebih mudah memahami fungsi-fungsi dan tampilan yang tersedia karena website ini dibangun berdasarkan masukan dari perangkat desa. Kemudian website yang sudah jadi langsung di publikasikan kepada masyarakat sebagai kemudahan dalam mengakses informasi di masyarakat. Sedangkan untuk Mobile, sebelumnya tim SIFORSA terlebih dahulu membuat Website dan mobile dengan mencoba dilingkungan sekitar. Setelah program ini berjalan dengan baik, maka

Teknologi Informasi dan Komunikasi 
program SIFORSA tersebut dibagikan ke perwakilan warga, dan setiap RT ada 2 perwakilan yang menerima Pelatihan sebagai percontohan terlebih dahulu, total RT di Desa Bringkang tersebut ada 33 RT. Setelah melakukan penyerahan website, dilakukannya pelatihan kepada warga cara penggunaan program dengan aplikasi yang sudah kami sediakan. Setelah itu dilakukan praktik penggunaan website dan mobile bersama, setiap 3 hari sekali dilakukan pengecekan, output dari program ini ada 2 jenis sistem sebagai hasilnya, yaitu Website desa dan aplikasi mobile. Program SIFORSA yang sudah dipraktikan maka diambil beberapa tanggapan untuk dilakukan kuesioner setelah adanya alat tersebut.

Dari sisi partisipasi warga sekitar $80 \%$ dan kemampuan warga dalam menggunakan website sendiri kurang lebih $80 \%$, kebermanfaatan program ini di Desa Bringkang masih sekitar $85 \%$

\section{KESIMPULAN}
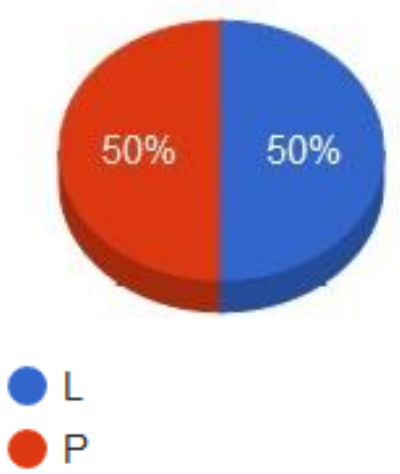

Gambar 10. Grafik jenis kelamin

Secara Keseluran gambaran data penduduk desa bringkang terbagi 50\% laki laki dan 50\% perempuan. Gambaran data penduduk berdasarkan jenis pekerjaan yaitu 15\% adalah pelajar, $15.4 \%$ mengurus rumah tangga, 3.8 persen wiraswasta, $30 \%$ karyawan swasta, $6.4 \%$ petani/pekebun, dan $24.6 \%$ tidak bekerja, sisanya terbagi menjadi profesi guru dan pensiunan. dari kegiatan pengabdian ini dapat disimpulkan jumlah partisipasi warga kurang lebih sebesar $80 \%$ dan kemampuan warga dalam menggunakan website sendiri sekitar $80 \%$, dan tim SIFORSA akan selalu memberikan pelatihan dan pendampingan kepada warga agar mereka dapat menggunakan website dan mobile untuk digunakan dengan baik dan menjadi suatu penambahan kompetensi dalam perangkat desa atau warga. sesuai dengan tujuan SIFORSA, kebermanfaatan program ini di Desa Bringkang masih sekitar 85\%, hal ini akan terus bertambah, karena kami masih melakukan pelatihan dan pemantauan sampai program PKM DIKTI selesai, dan kalaupun program ini selesai kami mempunyai harapan agar SIFORSA tetap terus berjalan.

\section{UCAPAN TERIMAKASIH}

Terima kasih kepada Tim Pelaksana Pengabdian Sistem Inforamsi Desa Bringkang dari Universitas Wijaya Putra. Tidak lupa terima kasih kepada seluruh perangkat desa Bringkang Kecamatan Menganti Gresik.

\section{REFERENSI}

A. M., \& Utama, S. N. (2018). IPTEK BAGI MASYARAKAT SISTEM INFORMASI MANAJEMEN ADMINISTRASI DESA BERBASIS WEB DI DESA SEKARAN KECAMATAN SIMAN - PONOROGO. Jurnal Terapan ABDIMAS, 1.

Apriyansyah, I. M., \& Purnomo, E. P. (2018). Efektivitas Sistem Informasi Desa (SID) Dalam Pelayanan Publik Di Desa Dlingo, Kecamatan Dlingo, Kabupaten Bantul. Jurnal Analisis Kebijakan dan Pelayanan Publik, 10.

Aris Widya, M. A., Y. A., Fibrian, I. D., \& Z. M. (2016). Upaya Peningkatan Pelayanan Administrasi Kependudukan Menggunakan Teknologi Informasi: Rancang Bangun Sistem Informasi di Desa Sumbermulyo Kecamatan Jogoroto Kabupaten Jombang. Jurnal Ilmiah Teknologi Sistem Informasi, 51.

D. F., \& D. M. (2017). PERANCANGAN SISTEM INFORMASI PENGOLAHAN DATA LAYANAN KEPENDUDUKAN BERBASIS WEBSITE DI KELURAHAN

Teknologi Informasi dan Komunikasi 
DESA CIPAGALO BANDUNG. Jurnal LPKIA, 63.

D. P., \& S. I. (2013). Sistem Informasi Data Penduduk Pada Desa Bogoharjo Kecamatan Ngadirojo Kabupaten Pacitan. IJNS, 55.

F. S., \& Dibyorin, C. R. (2013). Partisipasi Warga Terhadap Sistem Informasi Desa. Jurnal Komunikasi ASPIKOM, 579.

Fadilah, I. N., \& E. S. (2017). Prototype Sistem Informasi Data Kependudukan dan Potensi Desa Berbasis Website (Studi Kasus: Desa Tunjung Teja, Kabupaten Serang, Provinsi Banten). I-Statement, 113.

Mansur, \& Kasmawi. (2017). Pengembangan Sistem Database Terpadu Berbasis Web Untuk Penyediaan Layanan Informasi Website Desa. TEKNOSI, 73.
P. S., \& A. S. (2016). PERANCANGAN SISTEM INFORMASI DANA DESA DI KABUPATEN KUDUS. Jurnal SIMETRIS, 415.

S. H., \& C. M. (2015). Sistem Pelayanan Administrasi Kependudukan Desa Candigatak Berbasis Web. Jurnal IT CIDA, 42. 